\title{
Factors Contributing to the Subjective Career Success among Islamic Educators in Primary Schools
}

\author{
Mesnan Supa`ad \\ Faculty of Educational Studies, \\ Universiti Putra Malaysia, Selangor, Malaysia \\ Tel: 0060 17-325 8496 E-mail: mesnan_68@yahoo.com \\ Nor Wahiza Abd Wahat \\ Tel: $006012-2078054 \quad$ E-mail: wahiza@putra.upm.edu.my \\ Fathiyah Mohd Fakhruddin \\ Tel: $006013-2425573$ E-mail: fathi@upm.edu.my \\ Turiman Suandi \\ Tel: 006019 - 3952481 E-mail: turiman@putra.upm.edu.my
}

Received: 17-05- 2013

doi:10.7575/aiac.ijels.v.1n.1p.55
Accepted: 27-06- 2013

Published: 01-07- 2013

\begin{abstract}
A very limited research has been done in the field of career development among Islamic education teachers. Most of the previous researches showed an improvement in terms of grades, positions, and responsibilities of their previous routines as an indicator of their career advancement. However, this conceptual (concept paper) discusses how personality factors, career planning, and career strategy can provide significant contribution to the success of Islamic education teachers' career. Based on the Five Factor Model, Gould Planning Model, and the support of previous researches, this paper discusses how these three factors can contribute to the success of Islamic education teachers' career. This paper also discusses its impact towards Islamic education teachers in Malaysia, schools management, District Education Office, Ministry of Education, and teachers education institutions.
\end{abstract}

Keywords: Islamic educators, subjective career success, factors for subjective career success.

\section{Introduction}

Although studies on career advancement have been much discussed, contemporary studies continue to insist that more dynamic studies on career success are needed (Harris \& Ogbonna, 2006). Based on previous researches, it was indicated that there were various conceptual constructs that existed (independent variable) to ensure career success. However, in this paper, more focuses are given to subjective career success such as career advancement satisfaction and positive perceptions on career (Abele \& Wiese, 2008). This is also supported by Breland et al., (2007) as he emphasized that subjective career success refers to the individuals' satisfaction towards their achievement in career advancement.

Scholars have also emphasized on the importance of subjective career success as positive implications for psychological well-being and employees' quality of life (Gattiker \& Larwood, 1998; Nabi, 2003). Subjective career success is a utility that can be identified by instinct of the soul not based on mere observation or consent and acknowledgement (Nicholson \& De Waal-Andrews, 2005).

Subjective career success is also defined as an individual's reaction to the career experiences that happen directly or indirectly. The outcome of this can be assessed through personal standards of self-reference criteria or standards or achievement while others' criteria are used as a reference (Heslin, 2005). According to Ballout (2008), an employee's subjective career success achievement is more important than measuring objective career success such as rank, power and wages. Punnett (2007) found that higher wages do not necessarily give satisfaction to one's career.

Most of the literature reviews show little attention has been given to how the Islamic educators plan their careers to achieve career advancement and how they manage their careers to remain obscure. Moreover, studies on how Islamic educators' career advancement inspires them to better positions with fewer responsibilities are still limited. Although there have been a number of studies on career planning, career strategies, and career advancement among teachers, these studies, however, do not emphasize on subjective career success among Islamic educators.

Studies on Islamic educators' career advancement are seen as unique because the educators of this group do not only have very strong spiritual aspect (Sharifah Nooraida \& Shrifah Fatimah, 2011), but also positive personality and image 
(Syed Najmudin, Ab. Halim, Isahak \% Mohd. Sabri, 2009). According to Ibn Khaldun (2006), individuals with strong spiritual aspect are capable of having a better life. Hence, this paper seeks to observe how Islamic educators with strong spiritual aspect achieve career advancement in their teaching profession.

As a result of the ongoing effort by the Malaysia government to implement Islamic religious knowledge to students, Islamic education has become one of the core and compulsory subjects at primary school level. Its curriculum clearly emphasizes appreciation of Islamic faith, implementation of specific and general worship, apostles' history, good characteristics (KBSR,1993) as well as providing guidance in developing responsible attitude towards the Creator, mankind and nature (Mohd Roslan, Wan Mohd Tarmizi, 2011). This curriculum is developed based on the values derived from revelation of the Quran and the Sunnah in order to produce God-fearing and always worshipping Allah type of mankind (Abd Halim El-Muhammady, 1984; Abdullah Ishak, 1995). The curriculum implementation was strengthened by executing the Primary School Standard Curriculum after it had gone through stages of transformative process (KBSR, 2011).

Therefore, Islamic educators' career advancement is seen as facing with changes in the education curriculum due to the pressure and changes on the education progress towards producing human capital in the future. Besides being an important aspect of contributing ideas in making important decisions and a help in leading the schools, Islamic educators' career advancement is also important in the planning for schools' improvement, enhancing professional development, developing teachers' existing skills, and improving their communication skill with other teachers (HopeAvlene Tenell, 1999).

Subjective career success should be able to encourage Islamic educators in their career advancement; however, they are still not many of them who are among the headmasters or excellent teachers. This is because until January $31^{\text {st }}, 2013$, there were only $8(1 \%)$ Islamic educators who are among the headmasters while the other $585(99 \%)$ are not Islamic educators. For the whole Malaysia, there are 7028 teachers who are among headmasters, but only 48 of them are teaching Islamic education while the rest are teaching other subjects. Meanwhile, among the 1244 school's senior assistants (GPK) in Selangor, only 42 of them are teaching Islamic education. As for the whole Malaysia, 529 (3\%) of school's senior assistants (529) are also Islamic educators while 15,423 (97\%) are not Islamic educators. As for outstanding teachers (GC) in Selangor, there are 36 of them (8\%) who are teaching Islamic education. While the other $455(92 \%)$ outstanding teachers (GC) are not Islamic educators. Last but not least, the number of outstanding teachers (GC) in Malaysia are 3955; however, only 175(4\%) of them are Islamic educators (Education Management Information System MOE, 2013)

The Headmasters and Senior Assistants posts in primary schools are positions that refer to the employment warrant approved by the government through the Operating Budget Estimation (ABM) dedicated to PPPLD (Postgraduate Diploma in Education Service Officers) while outstanding teachers are promoted to Graduate Education Services Officers, but remain teaching. These positions are seen as career advancement driven by subjective success as to fulfill intrinsic success. In addition, these data have also shed some lights on the current situation of Islamic educators' career advancement and demonstrate that they need a shift that could propel their careers towards a more prestigious leading education.

This study is specifically carried out to identify the factors of subjective career success among Islamic educators in terms of career planning, career strategies and personality towards career advancement. This study also examines the relationship between demographic profiles, personality traits, career planning, career strategies and subjective career success. Based on the Five-Factor Model and Gould Planning Model theories, personality, career planning and career strategies are found to be related to subjective career success.

In order to clarify this relationship, Gould Planning Model is used in the study. According to this model, career planning and career strategy is the act of individual's behaviour to enhance career success. This is because individuals with career planning are capable of handling their own abilities and weaknesses and are always aware of the opportunities available. This situation certainly encourages these individuals to organize appropriate actions for the expected career advancement. Similarly, individuals with career advancement strategies are constantly improving their skills, seeking career guidance and building good social relationships with friends and superiors. In conclusion, this model explains the relationship between career planning, career strategies and career success among Islamic educators while the Five-Factor Model theory assists the subjective career success towards career advancement.

\section{Literature Review}

\subsection{Career Planning Factor}

Career planning refers to individual's initiative to set goals, explore options, and formulate plans that reflect an individual attempt to manage a career (De Vos, De Clippeleer \& Dewilde, 2009). Antoniu (2010) explains that career planning is a complex act that requires systematic and careful thought. By planning, employees can develop skills, knowledge, and new capabilities (Nwuche \& Awa, 2011). According to Juhary (2000), career planning is a process to create alternative measures designed to improve an individual's working system. Career planning can also help employees to have proper understanding of the power and the importance of their careers' success (Greenhaus, Callanan \& Kaplan, 1995; Chang, 2002; Chen et al., 2004). Patrick (2002) in a study of career goals among IT professionals in Singapore found that career should be managed with proper planning and strategies to avoid uncertainties.

Each employee's career goals should be specific and clear in order to determine how, when, and what one wants to accomplish (Chang at al., 2002). Goal setting in career planning will allow individuals to review to what extent the 
activities undertaken by them affect their current career success. In addition, career goals should be flexible, realistic and time bound. A study done by De Vos, De Clippeleer and Dewilde (2009) found a systematic career planning by graduates had become the strong basis of their subjective career success. Torrington, Hall, and Taylor (2008) suggested that employees should take great responsibilities in planning their careers if they want to achieve career success. Similarly, a survey conducted by Yean Fee Tan (2010) found that career planning factors influence subjective career success. Based on the above explanation, it can be concluded that the Islamic educators do have potentials in career advancement if proper attention is given to their career planning.

\subsection{Career Strategies Factor}

Kuo (2006) stated that career strategies are tactics that can be used by employees to help them achieve their career goals. According to Gould and Penley (1984), the use of successful career strategies will affect the career achievement. For example, getting guidance from a mentor (a type of career strategy) can help an individual improve his or her career by receiving feedback and valuable ideas that could help them to be successful in their subjective career success. It was also found in previous studies that there is a significant relationship between career strategies and career success.

This is proven by a study done by Farizoh Hamid (2006) in which he found that career strategies contributed the most to the Permintax Sanco Technologies employees' career success. Even Lloyd and Emmanuel (2006) in their qualitative study which involved interviews with 112 executives, managers, supervisors and front-line staffs of financial organizations and restaurants concluded that there are five key strategies to achieve career success. They are responsibility and exploitation, personal status growth, information acquisition and control, equations exploitation and action proactive. The study showed that more than $79 \%$ of the respondents interviewed developed career improvement strategies to achieve career success.

Fee Tan Yean and Khulida Kirana Yahya (2008) also examined the relationship between career strategies and subjective career success in their study. The study explored three-dimensional view of career strategies which are promotion opportunities, external relations reinforcement, and image enhancement with top management. The relationship between these two was then measured. A sample of 185 manufacturing employees was then studied and the result showed that there a significant relationship between career strategies and career success. However, only twodimensional career strategies were positively correlated with career success, namely, external relations reinforcement and image enhancement with top management. Multi-regression test results suggested that image enhancement strategy is the most important strategy that influences an individual's career success.

Fee Tan Yean (et al., 2010) again tested the relationship between career strategies and subjective career success among insurance agents in northern part of Peninsular Malaysia and found that career strategy influence subjective career success. Based on the findings of past studies, career strategy is hoped to influence the career success of Islamic educators.

\subsection{Individual Personality Factor}

Meaninger (1936) defines personality as an element that describes a person. According to Allport (1980), personality is a dynamic behaviour that constantly changes according to circumstances and environment or adapt well to an environment. Personality should reflect a person as a whole including how one thinks, reacts, and feels which makes one different from others.

Facts have shown that personality has a direct relationship with career satisfaction (Boudreau, Boswell and Judge, 2001). Personality appears to influence career satisfaction the most as a study done by John, Soo, Eric, Jeanie, and Anne (2004). Robie, Brown, and Bly (2005), Trouba (2005), and Sanders (2008) in their respective studies found that Fivefactor Model has complete personality traits to explain the whole dimensions of individual personality traits. The Fivefactor Model has been recognized as an important model to study personality traits that contribute to career success (Strang \& Kunhert, 2009).

In this paper, the personality theory of Five-factor Model theory has identified five key personality traits dimensions that are known by the acronym OCEAN, openness to experience, conscientiousness, extraversion, agreeableness, and neuroticism (McShane \& Von Glinow, 2005). Based on the personalty theory, this paper explains how these five personality factors influence subjective career success among Islamic educators.

To be more exact, Bolger (1990) stated that neuroticism influences stress coping strategy. Inclination to view tasks given negatively causes these educators to be less successful in their career and have less career satisfaction. They tend to feel scared and worried. These negative emotions encourage individuals to avoid doing tasks given to them. This condition is also associated with low self-efficacy as they expect to fail in the variety of tasks given to them. As a result, they will choose less satisfying tasks (less autonomy, less identity routine, not important, and easy to implement) because they are more suitable for those who are less concerned with their career achievement (Costa \& McCrae, 1980).

Furthermore, a study on a group of executive officers in the United States and Europe by Boudreau, Boswell, Judge, and Bretz (2001) found that extraversion has positive relationship with career satisfaction. Extraversion features show positive relationship with intrinsic career success and this finding showed the most consistent positive relationship between career success and career satisfaction. In addition to the study, agreeableness was found to have negative relationship towards career satisfaction. Intrinsic career success is influenced by extraversion, neuroticism and agreeableness. In short, individuals who are extroversive, less neurotic or have less agreeableness will experience higher career satisfaction level than their counterparts who agree with being less extroversive and more neurotic. 
Judge in their study found that openness to experience and agreeableness have a relatively weak relationship with job satisfaction. For example, extraversion is a perfect individual who wants to engage in social support (a type of career strategy) because they are sociable, and have the ability to expand their network to gain valuable career information, which may be important to achieve career satisfaction (Judge et al., 2002).

In a study by Harper and Irvine (2005), it was found that managers are successful not because of their highest achievement in academics, but their characteristics and personalities affect the success of their careers. Careers in reality faced uncertain environment. Thus, the stability of personal traits influences personal traits and influences an individual's spiritual to think, to become more motivated, to independently responding and to be optimistic in order to achieve career success.

Menwhile, Azlina and Lee (2011) stated that the teachers' the most dominant personality dimension is agreeableness such as being good-hearted, well-mannered, friendly, sympathetic, fun to work with and, approachable which allow teachers to achieve career success. The dimension of extraversion such as high-spirited, energetic, love to hang out, and socialize are the characteristics required by a teacher to ensure global education in order to work well and competently. In addition, teachers who have conscientiousness dimension are highly self-reliant, organized, reliable, responsible, consistent, and work hard. These will allow them to face the challenges of education, social problems, spiritual deterioration, and societal demands. Finally, the neuroticism dimensions help a teacher stabilize emotions, stay be able calm, able to face challenges such as Finally, the neuroticism dimensions help a teacher stabilize emotions, stay calm, and able to face challenges of social problems such as truancy, disobeying teachers, smoking and so on (Azlina \& Lee, 2011). By working in a fun, creative, healthy and positive environment, teachers will be able to achieve career success. Based on theories of personalities, the Five-factor Model, Gould Planning Model, and support from previous researches, subjective career success among Islamic educators can be simplified into a conceptual framework as below.

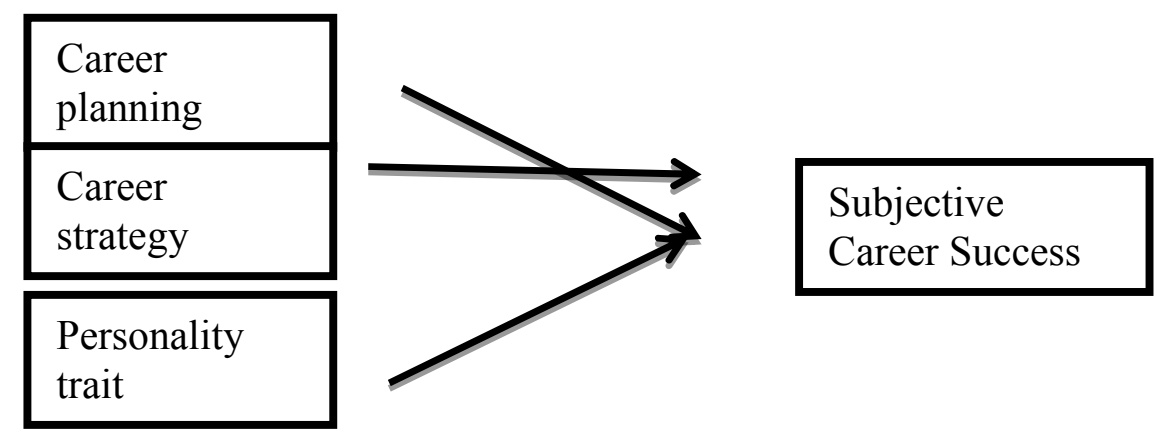

Figure 1: Framework of the Study

\section{Contribution of the Study}

Meager contribution of the research findings is on career planning factors, and personality characteristics of teachers and career strategies for subjective career success among Islamic education teachers. Past studies have been done in public universities (Maimunah \& Roziah, 2006), financial institutions (Van Emmerik, 2006), factory workers (Farizoh et al, 2006) and insurance services (Tan Yean Fee et al, 2010). Therefore, this study aims to pave the way for exploration of subjective career success among teachers of Islamic education in Malaysia. This study is important for teachers to be able to handle career advancement in Islamic education. This study assumes that Islamic education teachers have a career strategy that can catapult their career success. Similarly, by career planning, they can develop a career vision that allows them to achieve their career success. This is because through career planning, they can develop new skills and indirectly increase the sensitivity towards career advancement opportunities.

Personality factors are also seen crucial to career advancement of teachers of Islamic education. This is because personality is the expected behavior that can be observed and evaluated objectively. Current developments which saw the Islamic education teachers censured for poor student behavior (Fathiyah, Nor Hayati, Azimi \& Lukman, 2011), demanding the Islamic education teachers, in particular, committed to manage and to have high competitiveness in performing its role to feel more responsible towards the more prestigious. Positive personality will encourage career advancement of teachers of Islamic education. The findings of this study will then provide advice and guidance to the management of schools, District Education Office (DEO), Ministry of Education, Ministry of Higher Education, Malaysian Qualifications Framework Council and Teacher Education Institutions in order to develop human capital development and teacher emotional aspects of work and commitment of teachers who will disclose more stable than the emotional aspect and increase commitment to work toward improving teacher and excel potential students.

Aminullah (2009) in his study stated the teacher career success should not be at the same level during his tenure until mandatory retirement. MOE can provide courses, seminars, workshops and documented knowledge of the guidance and career knowledge. Teachers who have complete knowledge to develop and enhance career satisfaction will complete the package of MOE initiative to uphold the teaching profession. In addition, this study will hopefully help clarify the 
requirements subjective career success among teachers of Islamic education for career development, psychology to gain more recognition and appreciation primary responsibility within the organization.

\section{Conclusion}

Career success should not only be dreamed of by every individual but it should be actively pursued with hardworking attitude, effort, perseverance, hard work, discipline and care in everything. Only the person who is actually responsible for each action and strives to achieve success in his/her career will only get better returns. Typically, career success can give satisfaction to employees (Greenhaus, 1994; Heslin et al, 2005). Individuals are not born as champions, but rather they themselves shape it to be champions. Other aspects such as career planning, personality and career strategy differentiate employee achievements in their careers. However, other factors such as knowledge, experience, skills, opportunities, guidance and career path can boost career success within the framework of the process of managing the career wisdom. Therefore, future studies on the subjective success of Islamic education teacher may focus on these factors. Career advancement may be more meaningful for teachers of Islamic education that put the factors of knowledge, experience, skills and services in addition to the role of chance in career planning, career strategies and personality traits of teachers.

\section{References}

Abdul Halim El-Muhammady. (1984). Pendidikan Islam: Skop dan Matlamat. Angkatan Belia Islam Malaysia. Jurnal Pendidikan Islam, 1, 11.

Abdullah Ishak. (1995). Pendidikan Islam dan Pengaruhnya di Malaysia. Kuala Lumpur: Dewan Bahasa dan Pustaka.

Abele, A.E., \& Wiese, B.S. (2008). The nomological network of self-management strategies and career success. Journal of Occupational and Organizational Psychology, 81, 733-749.

Allport, D.A. (1980). Attention and performance, In G. Claxton (Ed.), Cognitive psychology: New directions. London: Routledge and Kegan Paul.

Aminullah Omar. (2009). Pengaruh personaliti proaktif dan motivasi pembelajaran ke atas pembangunan kerjaya, Tesis Sarjana tidak diterbitkan, Universiti Utara Malaysia.

Antoniu, E. (2010). Career planning process and its role in human resource development. Annals

of the University of Petroşani, Economics, 10(2), 13-22.

Azlina Mohd Kosnin dan Tan Sew Lee. (2012). Pengaruh personaliti terhadap kepuasan kerja dan stres kerja guru. Jurnal Teknologi, 48, 33-47.

Ballout, H.I. (2008). Work Family Conflict and Career Success, The Effect of Domain Specific Determinants, Journal of Management Development, 27(5), 437-466

Boudreau, J.W., Boswell, W.R., \& Judge, T.A. (2001). Effect of personality on executive career success in the United States and Europe, Journal of Vocational Behavior, 58(1), 53-81.

Breland, J. W., Treadway, D. C., Duke, A. B., \& Adams, G. L. (2007). The interactive effect of leader-member exchange and political skill on subjective career success, Journal of Leadership \& Organizational Studies, 13(3), 1-14.

Chang, P.B.L. (2002). Career Goal and Career Managemant Strategy Among Information Technology Profesional, Career Developmenrs International, 7(1), 6-13.

De Vos, A., De Clippeleer, I., \& Dewilde, T. (2009). Proactive career behaviours and career success during the early career. Journal of Occupational and Organizational Psychology, 82, 761-777.

Farizoh Hamid. (2006). The relationship between personality traits, career strategies and career success: A study among staffs in Permintex Sanko Technologies Sdn Bhd., Master Tesis not published, Universiti Utara Malaysia.

Fathiyah Mohd Fakhruddin, Nor Hayati Alwi, Azimi Hamzah dan Lukman Abd. Mutalib. (2011). Profesionalime guruguru pendidikan Islam dalam melahirkan modal insan berkualiti dan seimbang, Prosiding Seminar Majlis Dekan-dekan Pendidikan IPTA, Universiti Putera Malaysia,

628-645.

Gattiker, U.E. \& Larwood, L. (1988). Subjective career success: A study of managers and support personnel, Journal of Business and Psychology, 1(2), 78-94.

Greenhaus, J.H., Callanan, G.A. (1994). Career management, (2nd ed.) Fort Worth: The Dryden Press.

Greenhaus, J.H., Callanan, G.A., \& Kaplan, E. (1995). The role of goal setting in career success management, International Journal of Career Management, 7(5), 3-12

Gould, S.\& Penley,L. E. (1984). Career strategies and salary progression: A study the relationship in a municipal bureaucracy, Organizational Behavior and Human Performance, 34,244-265.

Harper, S.,\& Irvine, W. (2005). Qualification a fast-track to hotel general manager international, Journal of Contemporary Hospitality Management, 17(1), 51-64.

Harris, L.C., \& Ogbonna, E. (2006). Approaches to career success: An exploration of surreptitious career-success strategies. Human Resource Management, 45(1), 43-65. 
Heslin, P.A. (2005). Conceptualizing and evaluating career success, Journal of Organizational Behavior, 26(2), 113136.

Hope-Arlene, F. (1999). Encouraging teacher leadership. Presented paper in annual meeting the American Educational Research Association pada 19-23 April 1999, Montreal, Canada.

John W.L., James M.L., Eric D.Sundstrom. (2003). An investigation of personality traits in relation to career satisfaction, Journal of Career Assessment, 11(3), 287-307.

Judge,T.A., \& Kammeyer-Mueller, J.D. (2007), Personality and Career Success, Career Development International. Handbook of Career Studies, 59-78, Sage Publication, Thousand Oaks, CA.

Juhary Hj. Ali. (2000). Mengurus Sumber Manusia. Kuala Lumpur: Dewan Bahasa dan Pustaka, 75-85.

Kementerian Pendidikan Malaysia (1997), Buku Penerangan Kurikulum Bersepadu Sekolah Rendah. Kuala Lumpur: Pusat Perkembangan Kurikulum, 1.

Kuo, Y.F. (2006). Influence on employee career strategies adoption in the information service industry, superior leadership style or employee achievement motivation, Interbational Journal of Management, 23(1), 176-186.

Lloyd C. H. \& Emmanuel, O. (2006). An exploration of surreptitious career-success strategies. Human Resource Management, 45, 43-65.

McShane, S.L., \& Von Glinow, M.A. (2005). Organizational behavior: Emerging realities for the workplace revolution (3rd ed.), New York: McGraw-Hill.

Menninger, W. C. (1936). Individualization in the prescriptions for nursing care of the psychiatric patient, Journal of the American Medical Association, 106(10), 756-761.

Mohd Roslan Mohd Nor dan Wan Mohd Tarmizi Wan Othman (2011), Sejarah dan perkembangan Pendidikan Islam di Malaysia, Jurnal Ta'dib, 6, 1.

Nabi, G.R. (2003). Situational characteristics and subjective career success: The mediating role of career-enhancing strategies, International Journal of Manpower, 24(6), 653-672.

Nicholson, N., De Waal-Andrews. (2005). Playing to win: Biological imperatives, self-regulation, and trade-offs in the game of career success, Journal Organizational Behavior, 26(2), 137-154.

Nwuche, C.A., \& Awa H.O. (2011). Career planning and development: The realities in Nigerian

Organizations. International Business and Management, 2(2), 117-127

Patrick Chang Boon Lee. (2002). Career goal and career management strategy among information technology professionals, Career Development International, 7(1), 6-13.

Punnet, B.J., Duffy, J.A., Fox, S., Gregory, A., Lituchy, T., Miller, J., Monserrat, Santos, N.M.B.F. (2007). Career success and satisfaction: A comparative study in nine countries, Woman in Management Review, 22(5), 371-390.

Robie, C.,Brown, D.J.,\& Bly, P.R. (2005). The big five in the USA and Japan, Journal of Management Development, 24(8), 720-736.

Sanders, B.A. (2008) Using personality traits to predict police officer performance, An International Journal of Police Strategies \& Management, 31(1) 129-147.

Sharifah Nooraida, W.H., \& Sharifah Fatimah, W.J. (2011). Tinjauan keperluan aktiviti kerohanian dalam kalangan guru pelatih muslimah di ipg Kampus Batu Lintang. Jurnal Penyelidikan IPG Kampus Batu Lintang, Jilid 10, 1-13.

Sistem Maklumat Pengurusan Pendidikan, 2013, Data guru besar dan guru penolong kanan, guru

Cemerlang seluruh Malaysia, KPM, from http://www.moe.gov.my

Strang, S.E.,\& Kuhnert, K.W. (2009). Personality and leadership developmental levels as predictors of leadership performance: The Leadership Quarterly, 20, 421-433.

Syed Najmuddin Syed Hassan, Ab. Halim Tamuri, Isahak Othaman \& Mohd. Sabri Mamat. (2009). Kajian persepsi pelajar terhadap tahap profesionalisme guru pendidikan Islam MRSM. Journal of Islamic and Arabic Education, 1(2), $31-50$.

Tan Fee Yean. (2010). Career Planning, Individual's Personality Traits, HRM Practices As Determinants To Individual Career Success: The Role of Career Strategies as Mediator, Thesis PhD not published, University Utara Malaysia.

Tan Fee Yean \& Khulida K.Yahya. (2008). The relationship between career strategies and career

success, IJMS, Universiti Utara Malaysia, 15(1), 85-101 .

Torrington, D., Hall, L., \& Taylor, S. (2008). Human Resource Management $\left(7^{\text {th }}\right.$ ed.). London: Prentice Hall

Trouba, E.J. (2007). A person-organization fit study of the Big Five personality model and attraction to organizations with varying compensation system characteristics. Tesis PhD tidak diterbitkan, DePaul University, Chicago.

Van Emmerik, I.J.H., Euwerna, M.C., Geschiere, M.,\&Schouten, M.F.A.G. (2006). Networking your way through the organization: Gender differences in the relationship between network participation and career satisfaction, Women in Management Review, 21(1), 54-66. 